\title{
IAMJ
}

INTERNATIONAL

AYURVEDIC

MEDICAL JOURNAL

do) $\bigcirc$ (D

\section{PHARMACOGNOSTIC AND PHYTO-PHYSICOCHEMICAL EVALUATION OF Solanum xanthocarpum Serb. \& Wendl.}

\section{$\underline{\text { Biswa Jyoti Bora }}^{1}$, Dipak Kumar Goswami ${ }^{2}$}

${ }^{1}$ Lecturer, Dept. of Dravyaguna, Govt. Ayurvedic College, Guwahati (Assam), India

${ }^{2}$ Assistant Professor, Department of Prasuti Tantra and Stree Roga, Govt. Ayurvedic College, Guwahati-14, Assam, India

Corresponding Author: bjbora86@gmail.com

\section{https://doi.org/10.46607/iamj02p5052021}

(Published online: July 2021)

Open Access

(C) International Ayurvedic Medical Journal, India 2021

Article Received: 18/07/2021 - Peer Reviewed: 21/07/2021 - Accepted for Publication: 22/07/2021

\section{Check for updates}

\begin{abstract}
Medicinal plants are the backbone of Traditional systems of medicine like Ayurveda and Siddha. Solanum xanthcarpum (Solanaceae) (SX) is one of the most widely used medicinal herbs in Ayurvedic Pharmacopia. Medicinal plants have been of age-long remedy for human diseases because they contain components of therapeutic value. Plants are rich sources of ecologically developed secondary metabolites, which are potential remedies for different ailments. Kantakari (SX) of the family Solanaceae is one of the 'dasamoola' and widely used drugs in Ayurveda. Dasamoola means a combination of ten plant roots together. It comprises roots of five big or major trees (Brihat panchmoola) and roots of five small trees or major herbs (Laghu panchmoola). Various studies indicated that SX contains steroidal glycoalkaloid solasodine, $\beta$-solamagrine and solasonine. The indigenous uses of plants also indicate anti-inflammatory, Antispermatogenic, Antidiabetic, Antiasthmatic, Molluscidal activity, useful in infantile atopical dermatitis, Cytoprotective, anticancer, insecticidal, insect repellent properties and diuretic activities. Therefore, the present investigation was intended to evaluate the preliminary phytochemical characters of this plant. The data and results of Phytochemical studies in the present study would facilitate discovery for the synthesis of more potent drugs.
\end{abstract}

Keywords: Solanum xanthocarpum, Dasamoola, ethnobotanical uses, pharmacognosy, pharmacological activities, 


\section{INTRODUCTION}

The medicinal properties of plants are generally desired by the presence of secondary metabolites. Medicinal plants are the wealth of mankind. India with its mega-biodiversity and knowledge of rich ancient traditional systems of medicine (Ayurveda, Siddha, Unani, Amchi and local health traditions) provide a strong base for the utilization of a large number of plants in general healthcare and alleviation of common ailments of the people ${ }^{\mathbf{1}}$. Solanum xanthocarpum schrad. \& wendl., commonly known as Kantakari, belonging to Family Solanaceae is distributed in all districts in the plains \& low hills throughout India; also grows as a weed along roadside and wasteland. Solanum xanthocarpum, belonging to the Solanaceae family with an English name, Yellow berried nightshade is a prickly herb is an important plant species in Ayurveda and folklore medicine since time immemorial but there are meagre reports in the literature about its other potentials. In Ayurveda, the plant is supposed to possess pungent, bitter, digestive, alternative astringent properties. Root decoction is used as febrifuge, effective diuretic and expectorant. In ancient times, Charak and Sushruta used the entire plant for their medicinal perspective and fruits in an internal prescription for bronchial asthma, tympanitis and piles. This plant is found to be useful in the treatment of catarrhal fever, coughs, asthma and chest pain ${ }^{2}$. The indigenous uses of plants also indicate Antispermatogenic ${ }^{3}$, Antidiabetic $^{4}$, Antiasthmatic ${ }^{5}$, cytoprotective ${ }^{6}$, anticancer ${ }^{7}$ activity of the plant. It contains steroidal glycoalkaloid solasodine (about $0.2 \%$ ), steroidal saponine, solamargine, $\beta$-solamargine, solasonine and solacarpidine. Although $S$. xanthocarpum is important traditionally, lack of experimental research is a hindrance for its exploration in the modern system of medicine. Efficient research can blend the traditional knowledge with a modern experimental methodology for testing the efficacy and safe use of herbal drugs. An overview of $S$. xanthocarpum is presented to provide information and impetus to researchers for the profitable exploration of the plant species.

\section{OBJECTIVES OF THE STUDY}

1. To elucidate out a comprehensive review of the plant Solanum xanthocarpum.

2. To carry out Phytochemical analysis to screen, identify, extract and isolate the phyto-constituents to evaluate the therapeutic potential of Solanum xanthocarpum.

3. To develop phytochemical standards of Solanum xanthocarpum for standardization and quality control purposes.

\section{DRUG REVIEW ${ }^{8}$ :}

Taxonomical Classification of Kantakari as per Bentham and Hooker (1862-1883): Botanical name: Solanum xanthocarpum Schrad. and Wendl., Kingdom: Plantae, Sub-kingdom: Phanerogamia, Division: Angiospermae, Class: Dicotyledones, Subclass: Gamopetalae, Series: Bicarpellatae, Cohort: Polemoniales, Natural Order: Solanaceae, Family: Solanaceae Synonyms: Kshudra, Duhsparsha, Vyaaghri, Nidigdhika

Vernacular names: Hindi - Choti Kateri, English Yellow berried nightshade, Tamil - kandanakatiri, Telugu - Kuda

Botanical description: A very prickly diffused bright green perennial herb, fruits berry $1.3-2 \mathrm{~cm}$ diam. Fleshy, red when ripe, surrounded by enlarged calyx. Seeds $2.5 \mathrm{~mm}$ diam. glabrous, numerous embedded in fleshy mucilaginous mass (Fig.1,2,3). Flowering and fruiting time is from winter to summer. It is distributed almost throughout India, Sri Lanka, Southeast Asia and Malaysia.

\section{Pharmacodynamics as per Ayurveda :}

Rasa: Tikta, katu, Guna: Laghu, ruksha, tikshna,Virya: Ushna, Vipaka: Katu, Doshakarma: KaphaVatahara, Therapeutic Action: Kasahara, kanthya, shvasahara, mutrala, ashmarighna and krimighna, Therapeutic Use: Kasa, shvasa, parshvashoola, krimi, charmavikara, Part used: Whole plant, roots.

Dose: Decoction 40-80 ml. 


\section{Medicinal importance of Solanum} xanthcarpum:

Many traditional medicinal formulations include Solanum xanthocarpum as a major ingredient. For example, Vyaghriharitaki avaleha, Chavanaprasha, Dasamoolarishta, Vyaghri tailam, Vyaghri ghrtam, Vyaghriyadi kwatha, and shirishadi avaleha etc. Roshy et al, 2012, reported a detailed list of all the traditional formulations, which include the plant. The most popular Ayurvedic preparation, which includes the plant, is Dasamoolarishta. The plant is a part of laghupanchamoola in Dasamoolarishta. The whole plant, roots and fruits are used to treat various ailments such as vitiated conditions of Vata and Kapha, helminthiasis, dental caries, inflammations, flatulence, constipation, dyspepsia, anorexia, leprosy, skin diseases, hypertension, fever, cough, bronchitis, hiccough, lumbago, haemorrhoids and epilepsy. The plant is bitter, acrid, thermogenic, anthelmintic, anti-inflammatory, digestive, carminative, appetizer, stomachic, febrifuge, expectorant, laxative, stimulant, diuretic, rejuvenating, emmenagogue and aphrodisiac, and helpful in bronchial asthma, tympanitis, peristalsis, piles and dysuria. (Roshy et al, 2012; Reddy et al., 2014; Bhatt et al., 2018; Kajaria et al., 2013). Charaka and Sushruta used plant extracts in various treatments. Kantakari Ghrita of Charaka is mainly written for cough and asthma (Parmar et al., 2010).

An overview of the phytochemistry of $S$. xanthocarpum (SX): The plant is rich in alkaloids, glycosides, tannins, phenolics, flavonoids, proteins and amino acids, sterols, triterpenoid, carbohydrates, saponins, glycosides, fats and fixed oils (Reddy et al., 2014; Singh et al., 2010; Neelapu et al., 2011). The steroidal alkaloids and glycoalkaloids such as solasodine, solamargine, diosgenin and tomatidenol are present in the plant. The plant consists of steroids and triterpenoids, such as carpesterol, campesterol, sitosterol, cholesterol, stigmasterol and lupeol. Reports are available for the presence of flavones, phenolics and coumarins, such as apigenin, scopoletin, esculetin, coumarin, caffeic acid and methyl caffeate. Singh et $a l, 2010$ reported the presence of various phytochemicals in distinguished parts of the plant.

\section{MATERIALS AND METHODS}

Methods for Drug Collection and Authentication: Kantakari was collected from the natural Habitat from Jalukbari, Guwahati (Assam) and the plant sample was authenticated by the Department of Botany of Gauhati University, Guwahati (Assam) vide accession numbers 18799 .

Methods for Drug Analysis9: The sample was subjected for Organoleptic, Macroscopic and Microscopic Examinations as follows;

1. Organoleptic Evaluation: Qualitative Evaluation based on the sensory profiles refers to observation by colour, odour, taste and touch. Here the sample was subjected to the organoleptic evaluations.

2. Macroscopic Study: The macroscopic study refers to the physical evaluation of the drug in terms of size, shape, surface, fracture, etc. The sample was subjected to the macroscopic study with the help of a simple microscope and magnifying glass.

3. Method of Microscopic Examination: Transverse sections of the root of Solanum xanthocarpum Serb. \& Wendl..were prepared. Sections were cut with a razor, moisten the surface of the seed with glycerol solution, remove the section with a brush and place on the slide. The sections were treated with various reagents before examining.

4. Methods for Powder Analysis: All the root samples were made into a powder using a pulveriser to the size of coarse powder (Passing through 60 No mesh). Then all the powder samples were subjected to Macro and Microscopic examination. Then powder of the sample was tested for organoleptic characters like Colour, Appearance, Taste, Odour and Fineness. Examination for Lignin was done by moistening the powder with an alcoholic solution of Phloroglucinol and allowed to stand until nearly dry, added concentrated Hydrochloric acid. Apply a cover glass and examine. Note the presence or absence of lignified vessels, fibres, parenchyma, sclereids or hairs.

5) Methods for Determination of Foreign Matter': Weighed $100 \mathrm{gm}$ of the drug sample to be examined spread it out in a thin layer. The foreign matters were detected by inspection with the unaided eye or by the 
use of lens $5 x$, separated, weighed and calculated the percentage.

6) Methods for Extractions ${ }^{10}$ : Powder sample was subjected to Cold maceration method for extraction.

a) Alcoholic Extraction:

Equipments - Conical Flask: 2-litre Capacity, - Measuring Cylinder: 25-ml. capacities., - Silver Foil, Filter Paper, - Emulsion cloth. Other materials - (a) Filter Paper (b) $500 \mathrm{ml}$ beaker (c) Glass funnel, Ingredients Seed powder 5 gms and $100 \mathrm{ml}$ Ethanol

Procedure: Macerated $5 \mathrm{~g}$ of the air-dried drug, coarsely powdered, with $100 \mathrm{ml}$ of Ethanol in a closed flask for twenty-four hours, shaking frequently for six hours and allow to stand for eighteen hours. Filtered rapidly, taking precautions against loss of solvent, evaporated $25 \mathrm{ml}$ of the filtrate to dryness on waterbath in a tarred flat bottomed shallow dish, and dry at $105^{\circ}$, then cooled it.

\section{b) Aqueous extraction (water extract):}

Equipments - Conical Flask: 2-litre Capacity., - Measuring Cylinder: 25-ml. capacities., - Silver Foil, Filter Paper, - Emulsion cloth., Solvent - Distilled Water, Ingredients - 5 gm seed powder and Water (As required) Procedure: Macerated $5 \mathrm{~g}$ of the air-dried drug, coarsely powdered with $100 \mathrm{ml}$ of Distilled Water in a closed flask for twenty-four hours shaking frequently for six hours and allowed to stand for eighteen hours. Filtered rapidly, taking precautions against loss of solvent, evaporated $25 \mathrm{ml}$ of the filtrate to dryness on water-bath in a tare flat bottomed shallow dish, and dried at $105^{\circ}$, then cooled it.

7. Methods for preliminary phytochemical screening $^{11}$ : Both, aqueous and alcohol extracts were subjected for qualitative preliminary phytochemical screening:

a) Test for Reducing Sugars (Benedict's test): Mixed equal volume of Benedict's reagent and test solution in the test tube and heated on a water bath for 5 minutes. The solution appears green, yellow or red depending on the amount of reducing sugar present in the test solution.

b) Test for monosaccharides (Barfoed's test): Mixed equal volume of Barfoed's reagent and the test solution. Heat for 1-2 min. on a water bath and cool it. A red precipitate is observed.

c) Test for pentose sugars (Bial's Orcinol test): To boiling Bial's reagent added few drops of test solution. Green or purple colouration appears.

d) Test for hexo sugars (Selwinoff's test): Heated 3 $\mathrm{ml}$ Selwinoff's reagent and $1 \mathrm{ml}$. test solution on a water bath for 1-2 min. The red colour is formed.

e) Test for proteins (Million's test): Heated $3 \mathrm{ml}$ Million's reagent $1 \mathrm{ml}$. test solution.

f) Tests for steroids (Salkowski reaction): To $2 \mathrm{ml}$ of extract, add $2 \mathrm{ml}$ of chloroform and $2 \mathrm{ml}$ concentrated $\mathrm{H}_{2} \mathrm{SO}_{4}$ were added. Shaked well. A chloroform layer appears. The red and acid layer shows greenishyellow fluorescence.

g) Test for alkaloids (Wagner's Test): To 2-3 $\mathrm{ml}$ of filtrate with few drops of Wagner's Reagent shows reddish brown ppt.

h) Tests for tannins and phenolic compounds: To 2 $-3 \mathrm{ml}$ of aqueous or alcoholic extracts, add few drops of the following reagents: $5 \% \mathrm{FeCl}_{3}$ solution deep blue-black colour.

8. Chromatography ${ }^{12,13}$. Two grams of dried powder of Solanum xanthocarpum root was extracted with methanol by warming on a water bath. The extract was collected and placed in a vacuum evaporator for complete evaporation. The sample was carefully scratched, collected and again dissolved in methanol having AR grade and used for chromatographic fingerprinting. The solvent system used for Solanum xanthocarpum plant drug was Toluene: Ethyl acetate (7:3). Applied $5 \mathrm{ul}$ of test solution on precoated silica gel 60F 254 (E.Merck) of uniform thickness of $0.2 \mathrm{~mm}$. Developed the plate in the solvent system to a distance of $8 \mathrm{~cm}$. Observed the plate under UV 254nm, 366nm and white light. Noted the Rf value and colour of resolved bands.

\section{RESULTS:}

\section{Results Pharmacognostical study}

Macroscopic study reveals Kantakari (SX) root is long, cylindrical and tapering, bearing several fine longitudinal and few transverse wrinkles with occasional scars or a few lenticels and small rootlets, transversely 
smoothened surface show a thin bark and wide compact cylinder of wood, fracture is short and taste is bitter.

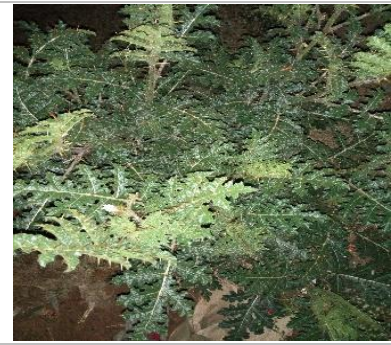

Fig.1: Leaves of SX

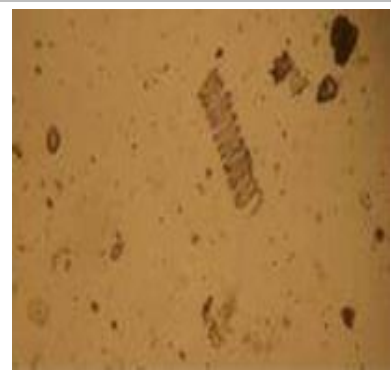

Fig.5 Stone Cells

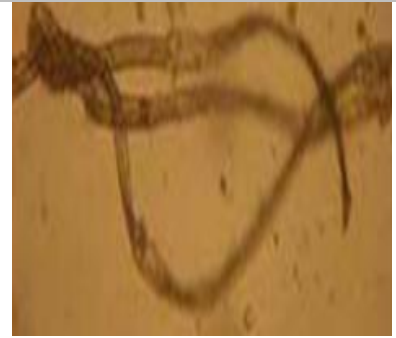

Fig 9:Fibres

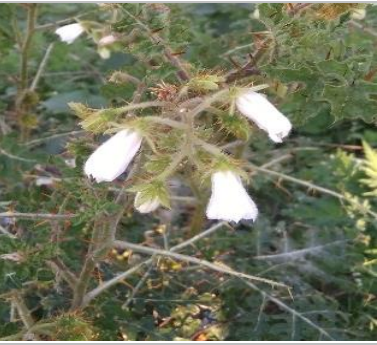

Fig.2: Flowers of SX

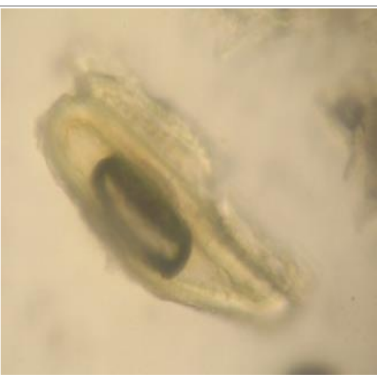

Fig.6 Spiral Vessels

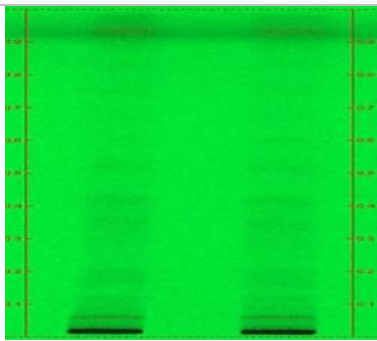

Under 254 nm

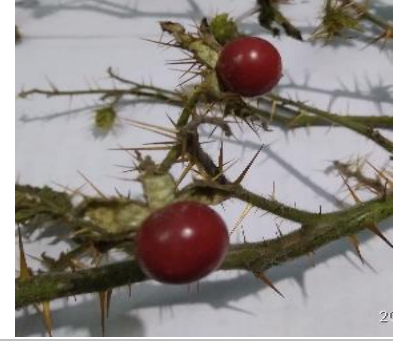

Fig.3: Fruits of SX

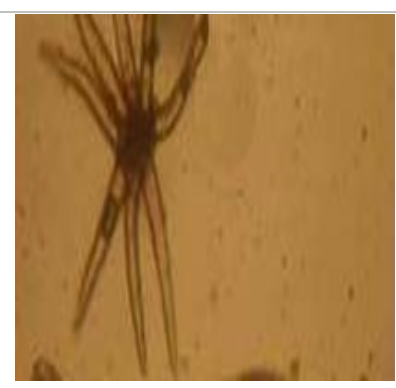

Fig 7: Trichome

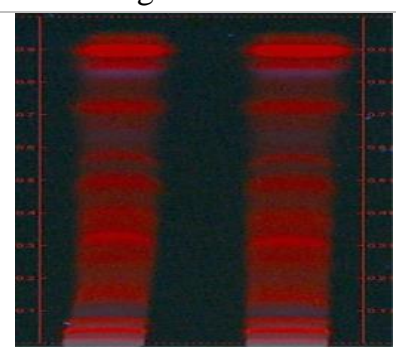

Under 366 nm

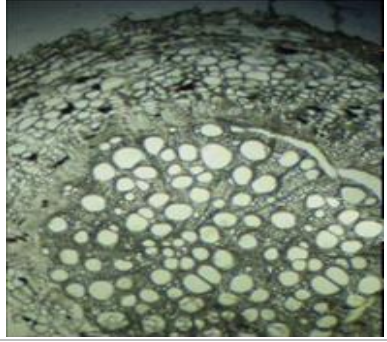

Fig.4 T.S of SX Root

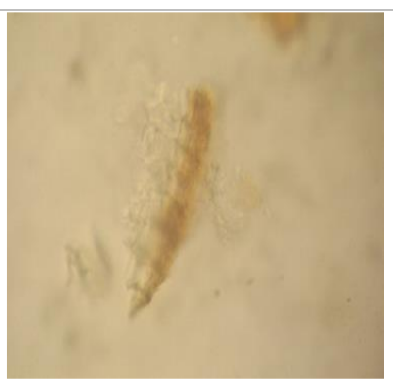

Fig 8: Cork Cells

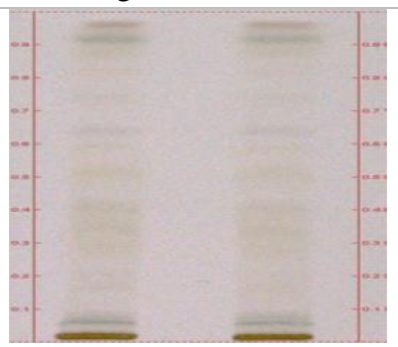

Under white light
Microscopic study of a transverse section of Kantakari root (SX) reveals the presence of epidermis, endodermis, phloem, xylem etc. Mature Kantakari root shows cork composing of thin-walled, rectangular and tangentially elongated cells, cork cambium single-layered followed by layers of thin-walled, tangentially elongated to oval or circular parenchymatous cells, stone cells either single or in groups, secondary phloem composed of sieve elements and phloem parenchyma traversed by medullary rays, xylem composed of vessels, tracheids, fibre tracheids, parenchyma and transverse by medullary rays, all elements being lignified, vessels and tracheids with bordered pits, fibres with a few simple pits, xylem parenchyma rectangular or lightly elongated with simple pits and rarely with reticulate thickening, crystals of calcium oxalate as sandy masses and simple starch grains present in the secondary cortex, phloem and medullary rays (Fig.4). The microscopic characters of root powder reveal the presence of stone cells, spiral vessels and multi-branch trichomes, cork cells and fibres (Fig.5,6,7,8,9). 
Table 01: Physicochemical analysis of Kantakari (SX) Root:

\begin{tabular}{|l|l|l|}
\hline Parameter & Recorded Value & Standard \\
\hline Foreign matter & $6.118 \%$ & NA \\
\hline Total Ash value & $3.178 \%$ & NA \\
\hline Acid insoluble ash & $1.209 \%$ & NA \\
\hline
\end{tabular}

Table 02: Extractive values of Kantakari (SX) Root:

\begin{tabular}{|l|l|l|l|}
\hline Sl. No & Solvent & Extractive Value recorded & API standard \\
\hline 01. & Water & $0.632 \%$ & Not less than $7 \%$ \\
\hline 02. & Ethanol & $18.524 \%$ & Not less than $4 \%$ \\
\hline
\end{tabular}

Table 03: Preliminary phytochemical screening of Kantakari (SX) Root Extracts:

\begin{tabular}{|c|l|l|l|}
\hline Sl.no & Name of Test & Alcoholic Extract & Aqueous Extract \\
\hline 1. & Test for Carbohydrates: & + & \\
& a) Benedict's Test & + & + \\
\hline & b) Fehling's Test & + & + \\
\hline & c) Molish Test & + & + \\
\hline 2. & Test for Phenolic compounds: & + & + \\
\hline 3. & Test for Tannins & + & + \\
\hline 4. & Test for Alkaloids: Wagner & + & - \\
\hline 5. & Test for Steroids: Salkowski & + & - \\
\hline 6. & Test for Proteins: Million's test & & \\
\hline 7. & Test for Flavonoids & + & + \\
\hline & With NaOH, & + & + \\
\hline & With $\mathrm{H}_{2} \mathrm{SO}_{4}$, & + & + \\
\hline & With $\mathrm{Mg} / \mathrm{HCl}$ & + & + \\
\hline
\end{tabular}

TLC ANALYSIS PROFILE: The TLC plate was examined under ultraviolet light at $254 \mathrm{~nm}$; at $366 \mathrm{~nm}$; at visible light (Fig. 10). The Rf values and colours of the bands obtained were recorded.

Table 04: Rf value @ $254 \mathrm{~nm}$

\begin{tabular}{|l|l|l|}
\hline Sl. No & Sample & Rf Values \\
\hline 01. & Kantakari (SX) Root & $0.06,0.92$ \\
\hline
\end{tabular}

Table 05: Rf value in $366 \mathrm{~nm}$

\begin{tabular}{|l|l|l|}
\hline Sl. No & Sample & Rf Values \\
\hline 01. & $\begin{array}{l}\text { Kantakari }(\mathrm{SX}) \\
\text { Root }\end{array}$ & $0.01,0.04,0.07,0.13,0.26,0.31,0.39,0.48,0.57,0.66,0.71,0.82,0.85,0.89,0.93$ \\
\hline
\end{tabular}

Table 06: Rf value in white light

\begin{tabular}{|l|l|l|}
\hline Sl. No & Sample & Rf Values \\
\hline 01. & Kantakari (SX) Root & $0.03,0.06,0.28,0.34,0.41,0.51,0.59,0.88,0.92,0.96$ \\
\hline
\end{tabular}




\section{DISCUSSION}

Herbal plants and plant-derived drugs have been widely used in traditional cultures everywhere in the world and gained popularity in modern society as natural alternatives to produce new potential therapeutic agents for combating diseases. The qualitative analyses of phytoconstituents (alkaloids, flavonoids, phenolics, saponins, steroids, tannins, carbohydrate, glycosides, terpenoids, and quinones) of $S$. xanthocarpum were carried out in the present study. Similarly, Yadav $^{14}$ et al. and Jaberian ${ }^{15}$ et al. analyzed the phytochemical nature of various medicinal plants, and their results were supported by the findings of the current investigation. The ethanolic extract of $S$. xanthocarpum exhibits the maximum number of phytochemicals than other extracts, which may be due to the polar nature of the solvent. This result was supported by Narender ${ }^{16}$ et al., which found that ethanol is used as a leading solvent for the extraction of a variety of plant constituents than other solvents. Kalita ${ }^{17}$ et al. stated that the flavonoid compounds from this medicinal plant exhibited better antioxidant properties.

\section{CONCLUSION}

An alternative system of medicine is a major component of health care globally and many healthcare providers and organizations are being forced to consider integrating them into their practice and treatment guideline ${ }^{18}$. The extensive survey of literature revealed that SX is an important source of many pharmacologically and medicinally important chemicals, especially steroidal hormone solasodine and other chemicals like solasonine, campestrol, campeferol, diosgenin and various useful alkaloids. The solasodine is the most studied chemical constituent of SX which has a role in the production of sex hormones. The plant is extensively studied for various pharmacological activities like antiasthmatic, hepatoprotective, cardiovascular, hypoglycemic and mosquito repellent properties. Various traditional claims like immunomodulation, hypolipidemic, antibacterial, sexual behaviour, tolerance and dependence are not studied to date and needs attention in this area to explore further medicinal values of this plant. Although the results from this review are quite promising for the use of SX as a multi-purpose medicinal agent, several limitations currently exist in the current literature. While SX has been used successfully in Ayurvedic medicine for centuries, more clinical trials should be conducted to support its therapeutic use. Moreover, the therapeutic potential of the plant should also be checked when used in combination with other herbal drugs.

\section{REFERENCES}

1. Pandey MM, Rastogi S, Rawat AK. Indian Herbal Drug for General Healthcare: An Overview. Internet J Altern Med 2008; 6: 1.

2. Ghani A; Medicinal plants of Bangladesh - chemical constituents and uses. Asiatic Society of Bangladesh, Dhaka, 1998.

3. Mali PC, Chaturvedi M \& Dixit VP, Journal of phytological Research, 1996; 9, 13-17.

4. Sharma R, Sharma AK, An indigenous drugs management of madumeha (Diabetes mellitus) Proceedings of International Congress on Ayurveda, Chennai, TN, India, 2000; 84, 28-30.

5. Govindan S, Viswanathan S, Vijaya sekaran V, Alagappan R, Phytother. Res., 2004; 18(10):805-809.

6. Prashanath KV, Cytoprotective role of solanum nigrum against gentamicin-induced kidney cell (vero cells) damage in vitro, Fitoterapia, 2001; 72,481-86.

7. Delorengzo MS, In vitro activity of a Solanum tuberosum extract against mammary carcinoma cells, Planta Med. (Germany), 2001; 67,164-66.

8. P.V. Sharma. Dravyaguna vijnana- 16 ed. Varanasi: Choukhamba Bharati Academy; 1995

9. Khandelwala K. R. "Practical Pharmacognosy", 9th edition, Nirali Prakashan. Pune; 2002.Pg.No.149-153.

10. Khandelwal K.R., "Practical Pharmacognosy" Nirali Prakashan Pune, Page 149- 153.

11. Khandelwal K.R., "Practical Pharmacognosy" Niraali Prakashan, Pune, Niraali Prakashan, Pune, (2006), Page no. 51, $67-69$

12. H Wagner; S Bladt, Plant Drug analysis of thin layer Chromatography atlas, Springer Germany, 1996, 147 174.

13. PE Wall, Thin-Layer Chromatography. Modern Practical Approach Series, The Royal Society of Chemistry, Thomas Graham House Cambridge-UK, 2005.

14. Yadav, D. K.; Singh, N.; Dev, K.; Sharma, R.; Sahai, M.; Palit, G.; Maurya, R. Anti-Ulcer Constituents of 
Annona Squamosa Twig. Fitoterapia. 2011, 82, 666675. DOI: 10.1016/j.fitote.2011.02.005.

15. Jaberian, H.; Piri, K.; Nazari, J. Phytochemical Composition and in Vitro Antimicrobial and Antioxidant Activities of Some Medicinal Plants. Food Chemistry. 2013, 136, 237-244. DOI: 10.1016/j.foodchem.2012.07.084.

16. Narender, P. D.; Ganga, R.; Sambasiva, E.; Mallikarjuna, T.; Praneeth, V. S. Quantification of Phytochemical Constituents and in Vitro Antioxidant Activity of Mesua Ferea Leaves. Asian Pacific Journal of Tropical Biomedicine 2012, 2, 539-542. DOI: 10.1016/S22211691(12)60269-X.

17. Kalita, P.; Barman, T. K.; Pal, T. K.; Kalita, R. Estimation of Total Flavonoids Content (TFC) and Antioxidant Activities of Methanolic Whole Plant Extract of Biophytum Sensitivum Linn. Journal of Drug Delivery Therapeutics 2013, 3, 33-37. DOI: 10.22270/jddt.v3i4.546.

18. J.L. Muller, K.A. Clauson. Am J Managed Care, 1997, 3(11), 1753-1770.

\section{Source of Support: Nil \\ Conflict of Interest: None Declared \\ How to cite this URL: Biswa Jyoti Bora \& Dipak Kumar Goswami: Pharmacognostic and Phyto-Physicochemical evaluation of Solanum xanthocarpum Serb. \& Wendl. International Ayurvedic Medical Journal \{online\} 2021 \{cited July, 2021\} Available from: http://www.iamj.in/posts/images/upload/2968 2975.pd}

